\title{
El lavado de activos
}

\author{
Prof. Ana María MENDOZA TORRES
}

El lavado de dinero es un grave problema, que perjudica no sólo a una nación sino también a todo el mundo, ya que este delito trae como consecuencia: La corrupción, agrava los males sociales y amenaza la integridad de las instituciones financieras. En la actualidad, la denominación "lavado de dinero" es obsoleta debido a que no sólo se "limpia" dinero proveniente de actividades ilícitas, sino también otro tipo de bienes, tales como propiedades, acciones, vehículos, por lo que lo apropiado es referirse a este ilícito penal como "lavado de activos".

En el Perú, el 26 de Junio del 2002 se promulgó la Ley Penal contra el Lavado de Activos (Ley $\mathrm{N}^{\circ} 27765$ ) la misma que extiende el Lavado de activos a otros delitos como fuentes generadoras de ganancias ilegales. El lavado de Activos es el conjunto de operaciones realizadas por una o más personas naturales o jurídicas, tendientes a ocultar o disfrazar el origen ilícito de bienes o recursos que provienen de actividades delictivas. Es el proceso de esconder o disfrazar la existencia, destino o uso ilegal de bienes, producto de actividades ilegales para hacerlos aparentar legítimos. Cuando un individuo obtiene dinero por medios ilegales o aunque lo consiga por medios legales, no declara este ingreso a las autoridades monetarias correspondientes, está creando lo que se conoce como dinero negro.

Involucra la ubicación de fondos en el sistema financiero, la estructuración de transacciones para disfrazar el origen, propiedad y ubicación de los fondos, y la integración de los fondos en la sociedad en la forma de bienes que tienen la apariencia de legitimidad. El dinero ilegal se blanquea en atención a los problemas contables, tributarios y criminalísticas que para los traficantes de droga, genera el hecho de tener que realizar todas sus operaciones de comercio de sustancias fiscalizadas en dinero efectivo. Las drogas no pueden pagarse a través de títulos valores o tarjetas de crédito que obligarían al traficante a registrar su identidad.

\section{FORMAS DE LAVADO DE ACTIVOS}

1. Estructurar: Uno o varios individuos hacen múltiples transacciones con fondos ilegales por cierto periodo de tiempo, en la misma institución o en varias instituciones financieras. 
2. Complicidad de un funcionario u organización: Cuando los empleados de las instituciones financieras o comerciales facilitan el lavado de dinero al aceptar a sabiendas grandes depósitos en efectivo, sin llenar ni presentar los informes de transacciones en efectivo cuando es necesario, exceptuando incorrectamente a los clientes de llenar los formularios requeridos.

3. Mezclar: Cuando se combina los productos ilícitos con fondos legítimos de una empresa, y después presenta la cantidad total como renta de la actividad legítima de tal empresa.

4. Compañías de fachada: La compañía de fachada puede ser una empresa legítima que mezcla los fondos ilícitos con sus propias rentas. Puede estar ubicada físicamente en una oficina o a veces puede tener únicamente un frente comercial.

5. Compras de bienes o instrumentos monetarios en efectivo: El lavador de dinero compra bienes tangibles (autos, propiedades, etc) o instrumentos monetarios (giros bancarios y postales, cheques de gerencia y valores) con el efectivo originado de la actividad criminal.

6. Contrabando de efectivo: Involucra el transporte físico del efectivo; puede estar escondido en el equipaje, o ser llevado por la persona que actúa de correo. A pesar de las limitaciones, los lavadores de dinero han demostrado un alto grado de imaginación al encontrar nuevos medios para mover el producto criminal en efectivo.

7. Transferencias telegráficas o electrónicas o electrónicas: Es la más usada para estratificar fondos ilícitos; en términos del volumen del dinero que puede moverse, y por la frecuencia de las transferencias. Ya que les permite enviar fondos a su destino rápidamente y el monto de la transferencia normalmente no está restringido.

8. Ventas fraudulentas de bienes inmuebles: El lavador compra una propiedad con el producto ilícito por un precio declarado mucho menor que el valor real.

9. La formación de compañías de portafolio o nominales: Es una entidad que generalmente existe solamente en el papel; no participa en el comercio ( a diferencia de una compañía de fachada).

Según Julio Sevares; en su obra "Dinero sucio" dice que el lavado de dinero alcanza magnitudes escandalosas, ya que la cantidad de dinero que circula es tan grande que se ha convertido en una amenaza, porque: Implica una evasión impositiva, reduce el control de los mercados monetarios de los países afectados. Constituye una inmensa "caja" disponible para financiar la corrupción y el delito, por lo cual vulnera los sistemas jurídicos y políticos. Por lo tanto, la 
debilidad de los gobiernos y las regulaciones no se debe a falta de visión o de decisión, sino a que delitos como el lavado no son excreciones marginales del sistema económico ni el producto de la actividad de un grupo de delincuentes profesionales, sino que son parte del mismo sistema.

En toda actividad de blanqueo se habla de dos categorías: Conversión y Movimiento. La conversión tiene lugar cuando los productos cambian de una forma u otra, como cuando se compra un giro o un automóvil con ganancias ilícitas; los productos ilícitos originales han cambiado de forma, de dinero en efectivo a un giro o a un automóvil. Se produce en Movimiento, cuando los mismos productos financieros cambian de localidades, como cuando los fondos son transferidos telegráficamente a otra ciudad o enviados a través del correo. El secreto bancario y el lavado de dinero son dos figuras jurídicas encontradas cuya conciliación por parte del banco, no siempre es fácil. Por un lado, deben resguardar el secreto de las operaciones que realizan con los clientes y, por otro lado, las disposiciones legales contra el delito de lavado les exigen que revelen ese secreto, cuando les sea requerido. Actualmente el desarrollo de la actividad bancaria se encuentra más que nunca entre el riesgo de ser utilizada con fines distintos a los que motivaron su existencia, debido a su condición de intermediarios de pago, a una mayor complejidad en sus operaciones internacionales.

Existen razones por las cuales el dinero y otros valores salen de los países en donde se ha comercializado la droga, con destino a otras jurisdicciones que ofrece privilegios y seguridades con respecto a secreto bancario. Algunas razones aparecen como legítimas o al menos no contrarias a la ley. Tales jurisdicciones reciben el nombre de PARAÍSOS FISCALES O FUNCIONALES.

Estos han llegado a ser tan populares en razón de ser considerados como uno de los medios para colocar una serie de fondos fuera del alcance de las investigaciones sobre la legalización de fondos derivados del tráfico de drogas. El problema se complicó con el desarrollo de los sistemas bancarios multinacionales, con lo que resultó más fácil dar una apariencia legal a todo el dinero que se obtenía ilícitamente de las actividades delictivas que se transferían a bancos extranjeros protegidos de la fiscalización de la ley. Para mencionar algunos bancos que son el paraíso de aquellos que lavan dinero tenemos:

Las Islas Caimán, islas Bahamas, islas Bermudas, islas Vírgenes, Luxemburgo, y más de 53 bancos. 


\section{Medidas que deben tomar las Instituciones Financieras, actividades y profesiones no financieras para impedir el Lavado de dinero.}

- Las Instituciones financieras no deberían mantener cuentas anónimas o bajo nombres evidentemente ficticios, sino que efectuar medidas de debida diligencia que incluya la identificación del cliente y verificación de los datos.

- Las empresas financieras han determinado que deberá quedar registro de aquellas operaciones iguales o superiores a 10,000 dólares o su equivalente en otras monedas. Deberán también registrarse todas las operaciones de canje que involucren transferencias o efectivo; el emisor y receptor de giros y transferencias de fondos; $y$ las operaciones que involucren el ingreso de cheques sobres realizadas.

- En relación con las personas expuestas políticamente, las instituciones deberán contar con sistemas de gestión de riesgos, obtener la aprobación de los directivos de mayor jerarquía para establecer relaciones comerciales con esos clientes. Tomar medidas razonables para determinar el origen de la riqueza y de los fondos.

- En lo que se refiere a las relaciones de corresponsalía bancaria transnacional y otras relaciones similares, las instituciones financieras deberían reunir información suficiente sobre un banco representado que le permita comprender cabalmente la naturaleza de sus negocios.

- Evaluar los controles instalados para el lavado de dinero de la institución representada.

- Las instituciones financieras deberían prestar especial atención a amenazas de lavado de dinero provenientes de tecnologías, nuevas o en desarrollo, que favorezcan el anonimato e impedir su uso.

- Las instituciones financieras deberían conservar, durante cinco años, los documentos necesarios sobre operaciones realizadas, tanto nacionales como internacionales, así como los datos de identificación de sus clientes, que le permitan cumplir rápidamente con las solicitudes de información de las autoridades competentes.

- Deberían prestar atención a las operaciones complejas e inusualmente grandes, que no tengan un objeto económico aparente o legítimo visible, analizando sus antecedentes y propósito. 


\section{BIBLIOGRAFÍA:}

. Alvarez, Pastor (Blanqueo de Capitales)

. Rojas, Fidel (Lavado de Activos)

. Montero Sáenz ( El Secreto bancario).

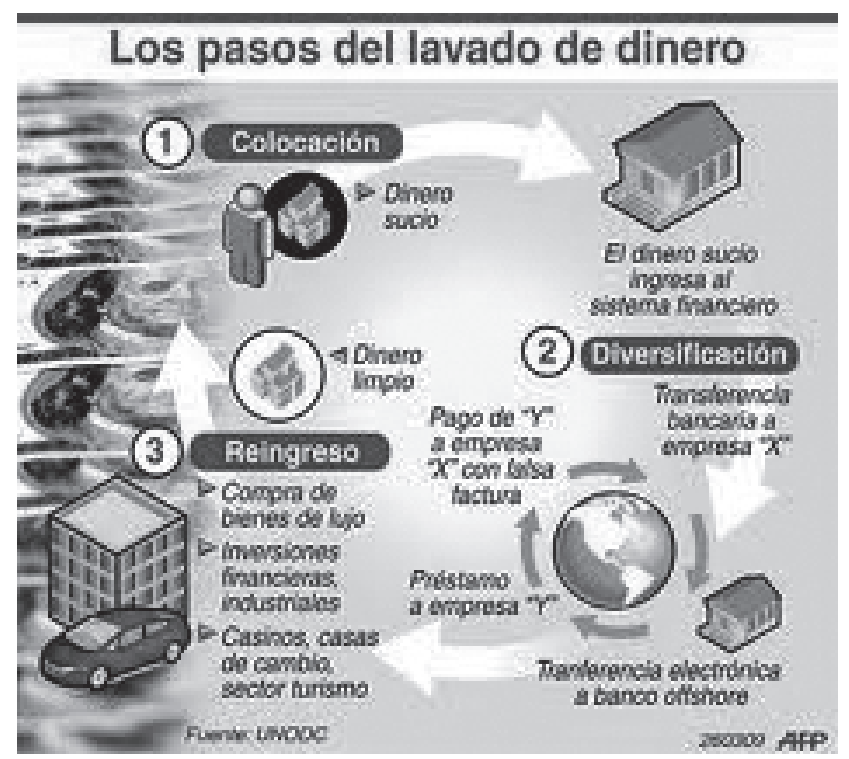


